\title{
Equine post-breeding endometritis: A review
}

\author{
Maischberger, E., Irwin, J.A., Carrington, S.D. and Duggan, V.E. \\ Veterinary Science Centre \\ School of Agriculture, Food Science and Veterinary Medicine \\ University College Dublin \\ Belfield, Dublin 4 \\ Ireland
}

\begin{abstract}
The deposition of semen, bacteria and debris in the uterus of the mare after breeding normally induces a self-limiting endometritis. The resultant fluid and inflammatory products are cleared by 48 hours post cover. Mares that are susceptible to persistent post-breeding endometritis (PPBEM) have impaired uterine defence and clearance mechanisms, making them unable to resolve this inflammation within the normal time. This persists beyond 48 hours post-breeding and causes persistent fluid accumulation within the uterus. Mares with PPBEM have an increased rate of embryonic loss and a lower overall pregnancy rate than those without the condition. To enhance conception rates, mares at high risk need optimal breeding management as well as early diagnosis, followed by the most appropriate treatment. This article reviews the pathogenesis, diagnosis and treatment of PPBEM and the management of affected mares.
\end{abstract}

Key Words: endometritis, equine, fertility, post-breeding

Irish Veterinary Journal Volume 61 Number 3 163-168, 2008

\section{Corresponding author:}

Eva Maischberger

Veterinary Science Centre

School of Agriculture, Food Science and Veterinary Medicine

University College Dublin

Belfield, Dublin 4

Ireland

Email: eva.maischberger@ucd.ie

\section{Introduction}

Persistent post-breeding endometritis (PPBEM) is the third most common medical condition of adult female horses (Traub-Dargatz et al., 1991) and the major reason for failure to conceive (Gutjahr et al., 2000). It affects approximately $15 \%$ of Thoroughbred mares after natural cover (Zent et al., 1998). Due to its association with decreased fertility, it is of major concern to breeders and veterinary practitioners (Watson, 2000).

Early embryonic death rates are three times higher in mares with this condition than in normal mares (Malschitzky et al., 2003), making it an important cause of loss to the bloodstock industry.

The aim of this article is to review the pathogenesis, diagnosis and treatment of PPBEM and the management of affected mares. It aims to provide breeders with a better understanding of the disease and enable them to optimise their breeding management in order to reduce its incidence. It also aims to update practitioners, allowing them to detect such mares early and administer the most appropriate and successful treatment.

\section{Pathophysiology of PPBEM}

Inflammation of the endometrium is caused by a response to exogenous materials introduced directly into the uterus at breeding (Troedsson et al., 2001). These include components of the semen, extender (in the case of AI), bacteria and other debris (Troedsson, 1999; Troedsson et al., 2001; Causey, 2006).

The normal endometrial inflammatory response, which is triggered by these antigens, is a predictable, physiological event (Troedsson et al., 2001). It is most commonly seen within a half to one hour of breeding (Katila, 1996) and is necessary to clear dead spermatozoa and bacteria from the uterine lumen (Troedsson, 1999).

The influx of polymorphonuclear neutrophils (PMNs) into the uterine lumen and their phagocytic activity after opsonisation of the target (Katila, 1996; Troedsson, 1999; Troedsson et al., 2001) is followed by myometrial contractions regulated by prostaglandin $\mathrm{F} 2 \alpha$ and oxytocin (Troedsson, 1999). This uterine defence mechanism peaks at around six to 12 hours post insemination (Katila, 1996). In the normal mare, most of the inflammatory products are cleared by physical uterine clearance mechanisms within 48 hours of cover (Katila, 1996). Because the embryo leaves the uterine tube and enters the uterus on about days five to six post-ovulation (Betteridge et al., 1982), the uterine inflammation has to be under control by 96 hours postovulation to maximise survival of the embryo (Troedsson, 1999). A mare that is susceptible to PPBEM is unable to clear such fluid by 96 hours and the resulting prolonged inflammation generates an embryo-toxic environment 


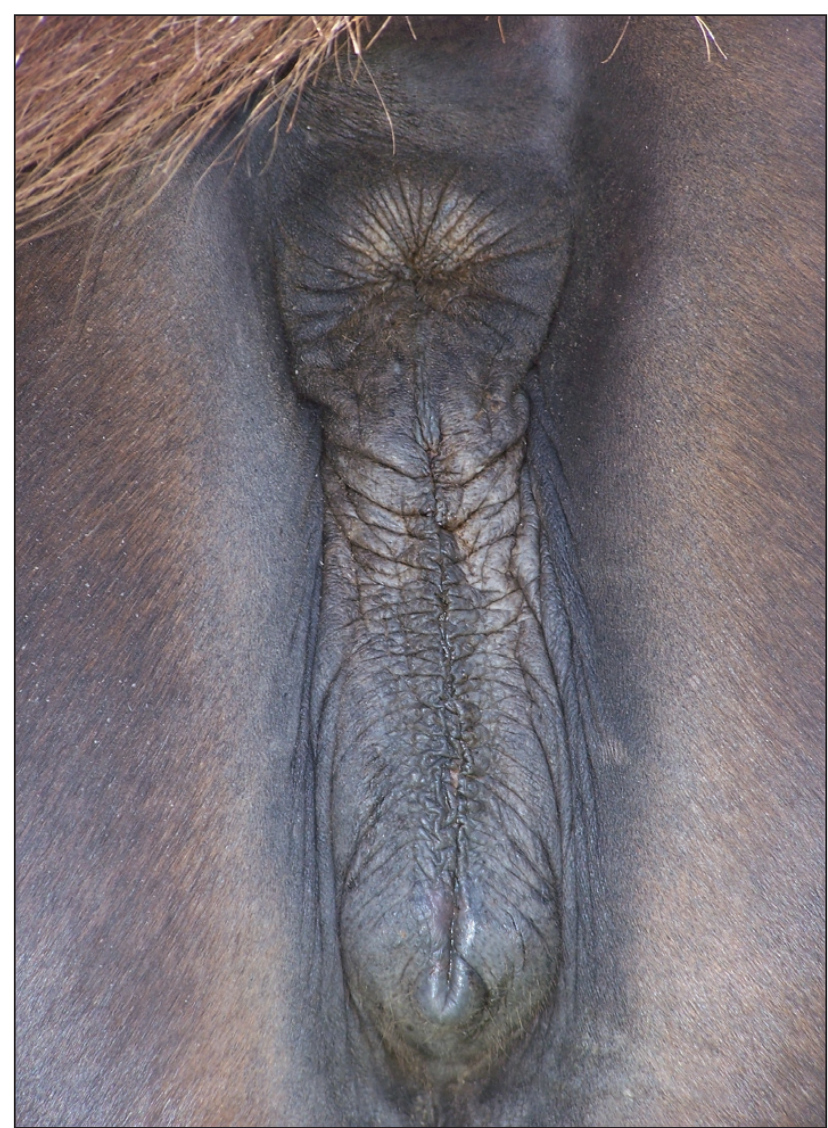

Figure 1a: A healthy vulva. The labiae of the vulva are symmetrical and the vulva itself is properly closed.

(Troedsson, 1999; Troedsson et al., 2001).

In addition to this, premature lysis of the corpus luteum is caused by complement products. Leukotriene B4, prostaglandin $\mathrm{E}$ and prostaglandin $\mathrm{F} 2 \alpha$ (Rambags et al., 2003), and subsequent progesterone deficiency, all contribute to embryo mortality (Rambags et al., 2003). Prolonged inflammation may be caused by several factors. Post-ovulatory artificial insemination (AI) more than 12 hours post-ovulation may influence the predisposition towards PPBEM, as rising progesterone levels may decrease uterine defence and uterine clearance (Katila, 1996; Watson et al., 2001). In contrast, AI undertaken between 12 hours pre-ovulation and four to eight hours post-ovulation has no influence on fluid accumulation or pregnancy rate (Watson et al., 2001). Two artificial inseminations within 24 hours during oestrus (in the absence of seminal plasma) profoundly reduce fertility, since the second insemination takes place when the uterine inflammation is at its peak (Alghamdi et al., 2004). Although spermatozoa can survive in a uterine environment already inflamed by an initial insemination, their motility is progressively reduced due to their aggregation with PMNs (Alghamdi et al., 2001). This results in a reduction in the number of viable spermatozoa reaching the uterine tube for fertilisation (Alghamdi et al., 2004; Troedsson et al., 2005).

The use of spermatozoa with reduced seminal plasma (as in frozen/thawed semen or sperm 'packed' from fresh semen by centrifugation) results in a more marked and prolonged inflammatory response (Troedsson et al., 2001), because seminal plasma is a modulator of sperm-induced inflammation (Troedsson, 1999; Troedsson et al., 2001) and protects viable spermatozoa from opsonisation and phagocytosis (Troedsson et al., 2001).

It is commonly assumed that mares that are susceptible to PPBEM are older maiden (LeBlanc et al., 1998; Pycock, 2006) or multi-parous mares (LeBlanc et al., 1998; Cadario et al., 1999a, 1999b; Hurtgen, 2006) with a history of repeated fluid accumulation (Pycock, 2006) and low fertility rates (Zent et al., 1998). However, new studies by Veronesi et al. (2006) show that the average age of normal mares (14 years) and susceptible mares (16 years) is not significantly different. Rigby et al. (2001) also suggest that myometrial dysfunction in mares with PPBEM is not dependent on age or pregnancy number.

Delayed uterine clearance of bacteria, fluid and debris following mating (Nikolakopoulos and Watson, 2000) may be caused by many different factors. These include: decreases in the frequency, intensity and duration of the myometrial activity (Nikolakopoulos and Watson, 1997; Troedsson, 1999; Rigby et al., 2001); vascular changes in the endometrium (Troedsson, 1999; Rigby et al., 2001); altered hormonal responses (Troedsson, 1999; Rigby et al. 2001); and, altered mucus production (Card, 2005; Causey, 2006). Other factors in multiparous mares include altered neuromuscular interactions (Rigby et al., 2001), or impaired lymphatic drainage (Causey, 2006) due to partial dilation of the uterus (Troedsson, 1999) or caudo-ventral displacement of the uterus (LeBlanc et al., 1998). All of these conditions enhance intrauterine inflammation and fluid accumulation (Troedsson, 1999; Guthjahr et al., 2000).

The vulva, vestibule, vagina and cervix normally act as physical barriers protecting the uterus from external contamination (Katila, 1996; Troedsson, 1999; Rambags et al., 2003) (Figure 1a). There is a higher predisposition towards PPBEM in mares with previous foaling injuries (Hurtgen, 2006), poor perineal conformation (Hurtgen, 2006), altered conformation of the vulva (Hemberg et al., 2005) (Figure 1b) and incomplete closure or persistent relaxation of the vulvar lips (Rambags et al., 2003; Hemberg et al., 2005). Therefore, the above abnormalities can all affect barrier function, causing air, faeces and urine to enter the reproductive tract (Hurtgen, 2006). In addition, cervical incompetence has consequences for both barrier function and uterine clearance. It may include either insufficient relaxation during oestrus with impaired cervical drainage (Hurtgen, 2006; Pycock, 2006) or improper closure during dioestrus (Rambags et al., 2003), predisposing to bacterial colonisation before breeding.

\section{Physical clearance mechanisms in PPBEM}

The equine uterus is strongly dependent on a physical clearance mechanism, which is based on ciliary beating and uterine contraction (Causey, 2007). An imbalance or breakdown of this sensitive system increases the risk of PPBEM in mares (Troedsson, 1999).

The equine endometrium consists of mucus secreting and ciliated cells (Causey, 2007). The cilia beat 13 times 


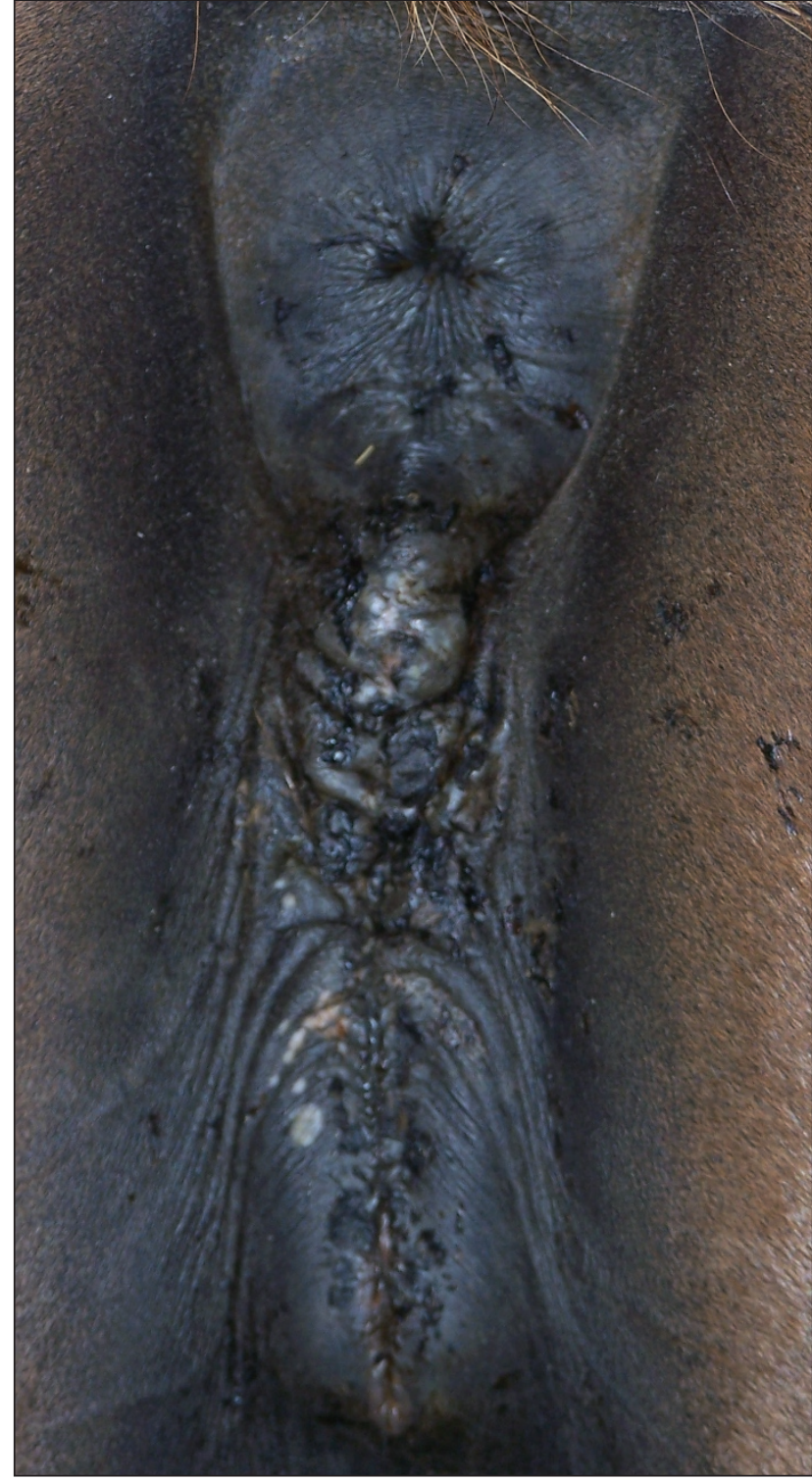

Figure 1b: Altered conformation of the vulva. The labiae do not create a proper seal and the rectum is displaced cranially, allowing the vulva to be pulled dorsal to the ischiatic arch, causing constant faecal contamination of the vulva and vestibule.

per second and help to transport mucus, fluid, bacteria and other debris along the longitudinal folds of the endometrium and the cervix (Causey, 2007). However, dilated capillary spaces between the folds and damaged, scarred or atrophic folds disturb this precise clearance mechanism (Causey, 2007). Ulceration, degeneration and lack of cilia are suggested to have the same effect (Causey, 2007).

Mucus overlies, hydrates and lubricates the endometrium (Lagow et al., 1999). It also prevents bacteria from binding to cell receptors (Lagow et al., 1999; Causey, 2006). Water, ions, specific antibacterial proteins (including lactoferrin, lysozyme and immunoglobulins) and mucins are the main components of the mucus-gel (Howe et al., 1999; Wiggins et al., 2001; Olmsted et al., 2003). Mucins are highly hydrated glycoproteins (Lagow et al., 1999; Wiggins et al., 2001). A change in the hydration of their polysaccharide chains is believed to disturb the viscosity and elasticity of the mucus (Causey, 2007). As a consequence, pathogens trapped in

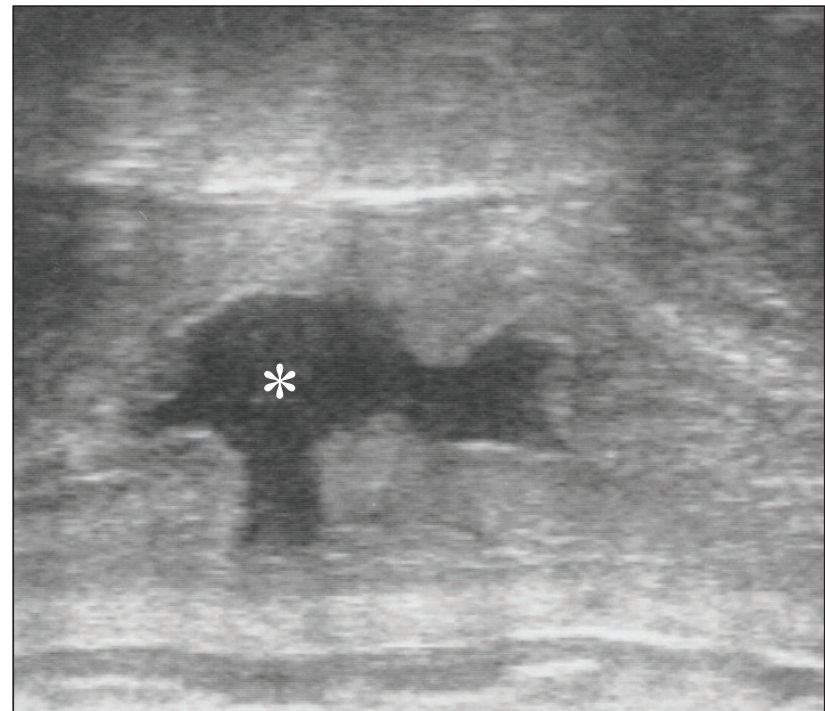

Figure 2: The presence of free fluid in the uterine lumen $(*)$ is diagnostic for the condition of PPBEM (Courtesy of Dr Christine Aurich, Vienna University).

the mucus and fluid are not cleared (Wiggins et al., 2001, Olmsted et al., 2003; Causey, 2007).

Smooth muscle cells form the inner circular and the outer longitudinal layer of the myometrium (Priedkalns and Leiser, 1998). It is hypothesised that contractile defects of the myometrium increase the susceptibility of mares to PPBEM (Nikolakopoulos and Watson, 1999; Rigby et al., 2001). Troedsson et al. (1993) showed that the myometrial electrical activity, which was measured 20 hours after bacterial challenge, was increased in both resistant and susceptible mares. However, resistant mares showed a greater increase in frequency, intensity and duration of uterine electrical activity compared to susceptible mares (Troedsson et al., 1993).

\section{Diagnosis of susceptible mares}

While PPBEM is easily diagnosed, its root causes are not always thoroughly investigated. A comprehensive assessment requires a detailed breeding history (Watson, 2000; LeBlanc, 2003). Any changes in perineal, vulvar or cervical conformation that predispose the mare to PPBEM should also be evaluated before breeding (Watson, 2000; LeBlanc, 2003; Hemberg et al., 2005). It is very important to check that the cervix opens properly in oestrus and closes in dioestrus. Routine pre-breeding uterine swabs should be obtained from 'at-risk' mares, using double-guarded swabs. These minimise contamination with cervical, vaginal or perineal bacterial flora (Causey, 2006), offering the possibility of isolating organisms that are characteristic of susceptible mares, such as non-haemolytic Escherichia coli and $\beta$-haemolytic Streptococcus (Albihn et al., 2003; Card, 2005; Nielsen, 2005). Bacteriology and cytology should always be conducted together, as the detection of PMNs together with potential pathogens is a much better indicator of the condition than bacteriology alone (Nielsen, 2005).

Following this initial examination, confirmation of a diagnosis of PPBEM is achieved using transrectal ultrasound examination 24 to 48 hours after breeding. The presence of free fluid in the uterine lumen (more than 15 
to $20 \mathrm{~mm}$ in diameter) (Watson et al., 2001; Barbacini et al., 2003; Brinsko et al., 2003) is diagnostic for the condition (Nikolakopoulos and Watson, 1999; Brinsko et al., 2003; LeBlanc, 2003; Guevenc et al., 2005) (Figure 2).

The earlier the diagnosis is made, the earlier the practitioner is able to start an effective treatment. This greatly enhances the chance of the mare carrying a foal to term. It is not uncommon that mares with a long history of normal fertility can spontaneously acquire PPBEM, giving the clinician no opportunity for prophylactic intervention (Watson, 2000).

\section{Treatment options}

The aim of the treatment is to completely clear fluid accumulation, contaminants and inflammatory products within 96 hours (Katila, 1996). This ensures that the embryo encounters a healthy endometrium at day five (Betteridge et al., 1982), thus facilitating implantation (Card, 2005).

A single dose of oxytocin (10-20 IU, IM) is usually enough to clear uterine fluid less than $20 \mathrm{~mm}$ in diameter (Pycock, 2006). If not, it should be repeated every four to six hours until the fluid is completely cleared (Pycock, 2006).

In mares with intra-uterine fluid accumulation of more than $20 \mathrm{~mm}$ in diameter, treatment should consist of uterine lavage (Pycock, 2006). One to two litres of warm, sterile saline or a $0.05 \%$ povidone-iodine solution $(5 \mathrm{ml}$ of a $10 \%$ povidone-iodine solution to each litre of balanced salt solution) (Brinsko, 2001) are infused via a large-bore equine embryo-flushing catheter until the recovered fluid is clear. This should be followed by administration of uterotonic substances such as oxytocin (Pycock, 2006); 10 IU preovulatory and $25 \mathrm{IU}$ post-ovulatory, IV or IM (Guthjahr et al., 2000).

Another option is the administration of cloprostenol (a prostaglandin analogue; $250 \mu \mathrm{g}$ IM daily, starting four hours after breeding) (LeBlanc, 2003) that clears the fluid more rapidly than PGF $2 \alpha$ and has a longer duration of activity compared to oxytocin (Combs et al., 1996). It is known that this drug has a negative effect on progesterone levels during early pregnancy (day two until day seven postovulation) when given throughout the periovulatory period until two days post-ovulation, but it does not decrease pregnancy rates, as the levels rise again at day seven and seem to be normal at day nine (Nie et al., 2003).

The mare is re-examined 24 hours after initial treatment. If fluid is still present, treatment is repeated (Pycock, 2006). For susceptible mares, treatment should be timed with breeding and it should not be delayed until ovulation occurs (LeBlanc, 2003; Pycock, 2006). As long as the mare is in oestrus, the cervix remains open, allowing the practitioner to perform several flushes before ovulation, if necessary (Pycock, 2006). Treatment should be delayed for four hours after breeding (Rigby et al., 1999). This allows enough time for the motile sperm to enter the uterine tube (Rigby et al., 1999).

The day upon which oxytocin is administered also plays an important role in the contractility of the endometrium (Gutjahr et al., 2000). It is suggested that mares that are susceptible to post-breeding endometritis should have more time between breeding (24-48 hours before ovulation) and ovulation (Gutjahr, 2000; Paccamonti and Lyle, 2003). Oxytocin treatment should be started in the pre-ovulatory period, as the response to oxytocin by the endometrium is higher when progesterone levels are low and oestrogen levels are high (Guthjahr et al., 2000).

If oxytocin treatment is used after ovulation, the dose should be increased to achieve an effect (Guthjahr et al., 2000; Paccamonti and Lyle, 2003). However, care has to be taken, as tetanic contractions can occur if more than $25 \mathrm{IU}$ of oxytocin are administered, leading to retention of uterine fluid (Cadario et al., 1999a). It is also suggested that an inflamed endometrium is more sensitive to oxytocin than a non-inflamed endometrium (Veronesi et al., 2006).

It is very important that the treatment is based on the individual mare, as standard treatment may not be effective in all cases (Pycock, 2006).

\section{Optimal breeding management}

Optimising the breeding management of the mare is the most important aspect in reducing the susceptibility of the mare for post-breeding endometritis, but it is also an aspect that is often underestimated. Prevention is always better than cure.

Choosing the right time for breeding or inducing ovulation (2,500 IU of hCG when the follicle has a diameter more than $35 \mathrm{~mm}$ ) (Samper, 2001; Pycock, 2006) reduces the need for more than one insemination during oestrus (Rambags et al., 2003; Pycock, 2006). Thus the spermatozoa are not exposed to an inflammatory uterine environment (Alghamdi et al., 2001; Troedsson et al., 2001).

Early breeding enhances the chance of accumulated fluid being expelled before the cervix starts to close rapidly after ovulation. In addition, the natural immune defence mechanisms of the endometrium are more pronounced during oestrus than in dioestrus (Katila, 1996; Pycock, 2006). With regard to breeding hygiene, bandaging the mare's tail and cleaning the vulva and perineal area with clean water help to minimise contamination during cover (Pycock, 2006).

AI with fresh or cooled semen is another means by which uterine inflammation can be reduced (but not eliminated), as exogenous bacterial contamination is limited (Pycock, 2006). It is very important to know that old mares bred with frozen semen are at a higher risk of developing PPBEM, as seminal plasma is reduced by the process of cryopreservation (Vidament et al., 1997; Troedsson et al., 2001). Therefore, its suppressive effect on post-breeding endometritis is lost (Troedsson et al., 2001).

New trends in insemination, for example the use of sexsorted (frozen-thawed) semen, require low sperm dose insemination techniques to achieve pregnancy (Sieme et al., 2003; Guevenc et al., 2005; Lyle and Ferrer, 2005). The uterotubal junction (UTJ) is the sperm reservoir in the mare (Lyle and Ferrer, 2005). Therefore, transrectally-, transendoscopically- or ultrasonographically-guided deep intrauterine horn insemination with a flexible catheter, onto 
or close to the UTJ papilla, is becoming more and more popular (Sieme et al., 2003; Guevenc et al., 2005; Lyle and Ferrer, 2005). Approximately one to $25 \times 10^{6}$ progressively motile spermatozoa in volumes between 20 and $1,000 \mu \mathrm{l}$ are needed (Lyle and Ferrer, 2005). This low number of spermatozoa is preferred when inseminating into the uterine horn ipsilateral to the dominant pre-ovulatory follicle to avoid increased inflammation in normal mares (Guevenc et al., 2005).

However, it should be borne in mind that these methods require a very skilled and experienced inseminator and that they seem to result in lower pregnancy rates in problem mares (Sieme et al., 2003).

Correction of anatomical defects, for example by Caslick's vulvoplasty operation, can protect and prevent the reproductive tract from constant external contamination, air aspiration (Causey, 2006) and ascending inflammation (Pycock, 2006).

\section{Conclusion}

Much research has been performed over the last few decades to determine the reasons for this multi-factorial condition in mares. There are also successful and accepted treatment programmes, which help improve pregnancy rates by completely clearing fluid early after breeding. However, more effective and rapid prognostic and diagnostic tests are required for improved management of PPBEM.

\section{Acknowledgements}

The authors are currently funded under the National Development Plan, through the Research Stimulus Fund, administered by the Department of Agriculture, Fisheries and Food. The authors would like to thank Mary Gallagher, Eamonn Fitzpatrick, Carolyn Cummins and Wilfried Schneeweiss for all their help.

\section{References}

Albihn, A., Baverud, V. and Magnusson, U. (2003). Uterine microbiology and antimicrobial susceptibility in isolated bacteria from mares with fertility problems. Acta Veterinaria Scandinavia 44: 121-129.

Alghamdi, A., Troedsson, M.H., Laschkewitsch, T. and Xue, J.L. (2001).

Uterine secretion from mares with post-breeding endometritis alters sperm motion characteristics in vitro. Theriogenology 55: 1019-1028.

Alghamdi, A.S., Foster, D.N. and Troedsson, M.H. (2004). Equine seminal plasma reduces sperm binding to polymorphonuclear neutrophils (PMNs) and improves the fertility of fresh semen inseminated into inflamed uteri. Reproduction 127: 593-600.

Barbacini, S., Necchi, D., Zavaglia, G. and Squires, E.L. (2003). Retrospective study on the incidence of postinsemination uterine fluid in mares inseminated with frozen/thawed semen. Journal of Equine Veterinary Science 23: 493-496.

Betteridge, K.J., Eaglesome, M.D., Mitchell, D., Flood, P.F. and Beriault, R. (1982). Development of horse embryos up to twenty two days after ovulation: observations on fresh specimens. Journal of Anatomy 135: 191209.

Brinsko, S.P. (2001). How to perform uterine lavage: indications and practical techniques. Proceedings American Association of Equine Practitioners 47: 407-411.
Brinsko, S.P., Rigby, S.L., Varner, D.D. and Blanchard T.L. (2003). A practical method for recognizing mares susceptible to post-breeding endometritis. Proceedings American Association of Equine Practitioners 49 363-365.

Cadario, M.E., Merritt, A.M., Archbald, L.F., Thatcher, W.W. and LeBlanc, M.M. (1999a). Changes in intrauterine pressure after oxytocin administration in reproductively normal mares and in those with a delay in uterine clearance. Theriogenology 51: 1017-1025.

Cadario, M.E., Thatcher, W.W., Klapstein, E., Merrit, A.M., Archbald, L.F., Thatcher, M.J., and LeBlanc, M.M. (1999b). Dynamics of prostaglandin secretion, intrauterine fluid and uterine clearance in reproductively normal mares and mares with delayed uterine clearance. Theriogenology 52: 1181-1192.

Card, C. (2005). Post-breeding inflammation and endometrial cytology in mares. Theriogenology 64: 580-588.

Causey, R.C. (2006). Making sense of equine uterine infections: the many faces of physical clearance. Veterinary Journal 172: 405-421.

Causey, R.C. (2007). Mucus and the mare: How little we know.

Theriogenolgy 68: 386-394.

Combs, G.B., LeBlanc, M.M., Neuwirth, L. and Tran, T.Q. (1996). Effects of prostaglandin F2 [alpha], cloprostenol and fenprostalene on uterine clearance of radiocolloid in the mare. Theriogenology 45: 1449-1455.

Gutjahr, S., Paccamonti, D.L., Pycock, J.F., Taverne, M.A., Dieleman, S.J. and van der Weijden, G.C. (2000). Effect of dose and day of treatment on uterine response to oxytocin in mares. Theriogenology 54: 447-456.

Guevenc, K., Reilas, T. and Katila, T. (2005). Effect of insemination dose and site on uterine inflammatory response of mares. Theriogenology 44 : 2504-2512.

Hemberg, E., Lundeheim, N. and Einarsson, S. (2005). Retrospective study on vulvar conformation in relation to endometrial cytology and fertility in thoroughbred mares. Journal of Veterinary Medicine Series A 52: 474-477.

Howe, L., Wiggins, R., Soothill, P.W., Millar, M.R., Horner, P.J. and Corfield, A.P. (1999). Mucinase and sialidase activity of the vaginal microflora: implications for the pathogenesis of preterm labour. International Journal of STD and AIDS 10: 442-447.

Hurtgen, J.P. (2006). Pathogenesis and treatment of endometritis in the mare: a review. Theriogenology 66: 560-566.

Katila, T. (1996). Uterine defence mechanisms in the mare. Animal Reproduction Science 42: 197-204.

Lagow, E., DeSouza, M.M. and Carson, D.D. (1999). Mammalian reproductive tract mucins. Human Reproduction Update 5: 280-292. LeBlanc, M.M., Neuwirth, L., Jones, L., Cage, C. and Mauragis, D. (1998). Differences in uterine position of reproductively normal mares and those with delayed uterine clearance detected by scintigraphy. Theriogenology $\mathbf{5 0}$ : 49-54.

LeBlanc, M.M. (2003). Persistent mating induced endometritis in the mare: pathogenesis, diagnosis and treatment. In: B.A. Ball (ed.) Recent Advances in Equine Reproduction. New York: International Veterinary Information Service.

Lyle, S.K. and Ferrer, M.S. (2005). Low-dose insemination - Why, when and how. Theriogenolgy 64: 572-579.

Malschitzky, E., Schilela, A., Mattos, A.L.G., Garbade, P., Gregory, R.M. and Mattos, R.C. (2003). Intrauterine fluid accumulation during foal heat increases embryonic death. Pferdeheilkunde 19: 246-249.

Nie, G.J., Johnson, K.E., Wenzel, J.G. and Braden, T.D. (2003). Effect of administering oxytocin or cloprostenol in the periovulatory period on pregnancy outcome and luteal function in mares. Theriogenology 60: 11111118 . 
Nielsen, J.M. (2005). Endometritis in the mare: a diagnostic study comparing cultures from swab and biopsy. Theriogenology 64: 510-518. Nikolakopoulos, E. and Watson, E.D. (1999). Uterine contractility is necessary for the clearance of intrauterine fluid but not bacteria after bacterial infusion in the mare. Theriogenology 52: 413-423.

Olmsted, S.S., Meyn, L.A., Rohan, L.C. and Hillier, S.L. (2003).

Glycosidase and proteinase activity of anaerobic gram-negative bacteria isolated from women with bacterial vaginosis. Sexually Transmitted Diseases 30: 257-260.

Paccamonti, D.L. and Lyle, S.K.(2003). Therapeutic considerations or pharmacological treatment of delayed uterine clearance. Pferdeheilkunde 19: 656-659.

Priedkalns, J. and Leiser, R. (1998). Female Reproductive System. In: Textbook of Veterinary Histology. Fifth edition, pp 247-261. Edited by H.D. Dellmann and J.A. Eurell. Baltimore: Lippincottt, Williams and Wilkins. Pycock, J.F. (2006). How to maximize the chances of breeding successfully from the older maiden mare. Proceedings American Association of Equine Practitioners 52: 245-249.

Rambags, B.P.B. (2003). Early pregnancy loss in aged mares: probable causes and cures. Pferdeheilkunde 19: 653-656.

Rigby, S., Hill, J., Miller, C., Thompson, J., Varner, D., and Blanchard, D. (1999). Administration of oxytocin immediately after insemination does not improve pregnancy rates in mares bred by fertile or subfertile stallions. Theriogenology 51: 1143-1150.

Rigby, S.L., Barhoumi, R., Burghardt, R.C., Colleran, P., Thompson, J.A., Varner, D.D., Blanchard, T.L., Brinsko, S.P., Taylor, T., Wilkerson, M.K. and Delp, M.D. (2001). Mares with delayed uterine clearance have an intrinsic defect in myometrial function. Biology of Reproduction 65: 740747.

Samper, J.C. (2001). Breeding mares with frozen semen in private practice. Proceedings American Association of Equine Practitioners 47: 314-318.

Sieme, H., Bonk, A., Ratjen, J., Klug, E. and Rath, D. (2003). Effect of number and site/technique of insemination on pregnancy in mares. Pferdeheilkunde 19: 677-683

Traub-Dargatz, J.L., Salman, M.D. and Voss, J.L. (1991). Medical problems of adult horses, as ranked by equine practitioners. Journal of American Veterinary Association 198: 1745-1747.

Troedsson, M.H., Liu, I.K., Ing, M. and Thurmond, M. (1993). Multiple site electromyography recordings of uterine activity following an intrauterine bacterial challenge in mares susceptible and resistant to chronic uterine infection. Journal of Reproduction and Fertility 99: 307-313. Troedsson, M.H. (1999). Uterine clearance and resistance to persistent endometritis in the mare. Theriogenology 52: 461-471.

Troedsson, M.H., Loset, K., Alghamdi, A.M., Dahms, B. and Crabo, B.G. (2001). Interaction between equine semen and the endometrium: the inflammatory response to semen. Animal Reproduction Science 68: 273-278. Troedsson, M.H., Desvousges, A., Alghamdi, A.S., Dahms, B., Dow, C.A., Hayna, J., Valesco, R., Collahan, P.T., Macpherson, M.L., Pozor, M. and Buhi, W.C. (2005). Components in seminal plasma regulating sperm transport and elimination. Animal Reproduction Science 89: 171-186.

Veronesi, M.C., Carluccio, A., Kindahl, H., Faustini, M., Battocchio, M. and Cairoli, F. (2006). Oxytocin-induced PGF2 alpha release in mares with and without post-breeding delayed uterine clearance. Journal of Veterinary Medicine Series A 53: 259-262.

Vidament, M., Dupere, A.M., Julienne, P., Evain, A., Noue, P. and Palmer, E. (1997). Equine frozen semen: Freezability and fertility field results. Theriogenology 48: 907-917.

Watson, E.D. (2000). Post-breeding endometritis in the mare. Animal
Reproduction Science 60-61: 221-232.

Watson, E.D., Barbacini, S., Berrocal, B., Sheerin, O., Marchi, V., Zavaglia, G. and Necchi, D. (2001). Effect of insemination time of frozen semen on incidence of uterine fluid in mares. Theriogenology 56: 123-131.

Wiggins, R., Hicks, S.J., Soothill, P.W., Millar, M.R. and Corfield, A.P. (2001). Mucinases and sialidases: their role in the pathogenesis of sexually transmitted infections in the female genital tract. Sexually Transmitted Infections 77: 402-408.

Zent, W.W., Troedsson, M.H.T. and Xue, J-L. (1998). Postbreeding uterine fluid accumulation in a normal population of thoroughbred mares: a field study. Proceedings of American Association of Equine Practitioners 44: 64-65. 